\title{
Massive flights of chironomid midges (Diptera) found on the shoreline of Lake Kawaguchi, Japan during the spring season
}

\author{
Kimio Hirabay ASHI ${ }^{1)}$ and Shinsuke WatANABE ${ }^{2)}$ \\ 1) Liberal Arts (Biology), Yamanashi Women's College, \\ 5-11-1, Iida, Kofu, Yamanashi, 400 Japan \\ ${ }^{2)}$ Biology, Fuji Kawaguchiko High School, 6663-1, Funatsu, \\ Kawaguchiko, Minamituru, Yamanashi, 401-03 Japan
}

(Received: 15 April 1996; Accepted: 27 May 1996)

\begin{abstract}
Key words: Lake Kawaguchi, nuisance insects, chironomid midges, seasonal abundance, shoreline population
\end{abstract}

\begin{abstract}
The species composition and abundance of the chironomid midges were investigated by using a board trap during the period from March to May 1994 at three different stations along the shoreline in the eastern part of Lake Kawaguchi. A total of 38,498 adult midges were collected, the great majority $(98.4 \%)$ of which were Biwatendipes tsukubaensis Sasa et Ueno. This was followed by Glyptotendipes tokunagai Sasa, (1.1\%) and then a very low representation of Chironomus yoshimatsui Martin et Sublette and C. plumosus Linnaeus (0.5\%). The dominant species of chironomids which emerged from the littoral region of the lake, however, changed with the month. First, massive emergence of $B$. tsukubaensis began from mid-March to late April, and then $G$. tokunagai from late March to early May. From mid-April, $C$. yoshimatsui emerged and was followed by $C$. plumosus. Thus, the period in which the four main chironomid species continuously emerged was from mid-March to early May. Therefore, throughout the spring season people living around the lake have the strong impression that the nuisance of chironomid midges has continuously increased and that these are attracted to the light of hotels, houses and some buildings during the breeding season.
\end{abstract}

\section{INTRODUCTION}

The non-biting chironomid midges (Diptera) include a number of species whose larvae live in almost all types of water bodies (Sasa and Kikuchi, 1995). They are often dominant in eutrophic lakes, and massive emergence of adults sometimes is a serious nuisance, as well as creating economic problems, to people living near lakes (Tabaru et al., 1987; Ali, 1980, 1991; Hirabayashi, 1991a, b, c). Furthermore, recently it has been reported by many researchers that the chironomid particles are one of the important inhalant antigens causing asthma (Kay et al., 1978; Igarashi et al., 1987; Murakami et al., 1986; Ishii et al., 1988).

Lake Kawaguchi is one of the Fuji Five Lakes (L. Yamanaka, L. Kawaguchi, L. Sai, L. Shoji and L. Motosu), which are especially familiar to Japanese for their beautiful landscapes. More than $10,000,000$ tourists visit these lakes and Mt. Fuji annually. Since the end of the 1960's, Lake Kawaguchi seems to be undergoing eutrophication (Yamanashi Prefecture, 1993). Several ecological studies on chironomids were reported from Lake Kawaguchi (Miyadi, 1932; Kitagawa, 1973; Yasuno et al., 1983). Most of them focused on pro- 
fundal and/or sublittoral regions, but the chironomid fauna in the littoral and hydrophyte regions in this lake have been less studied.

Every year, around the lake, especially at the southeastern part, enormous numbers of adult chironomid midges are attracted to the light of resort hotels, houses and some buildings, and massive accumulations of living and dead bodies have been observed during the spring season.

In order to determine the species composition and abundance of the chironomid midges, investigation by a board trap was carried out during the period from March to May 1994.

\section{Study Site}

Lake Kawaguchi $\left(35^{\circ} 31^{\prime} \mathrm{N}, 138^{\circ} 45^{\prime} \mathrm{E}\right.$ at the center of the lake; surface area 5.96 $\mathrm{km}^{2}$; maximum depth $16.1 \mathrm{~m}$; mean depth $9.3 \mathrm{~m}$; altitude above sea level $832 \mathrm{~m}$ ) is located at the northern foot of Mt. Fuji. There is a small island in the center of the lake, which is called Unoshima (Fig. 1). Cladophora sauteri $f$. Kurilensis (Nagai) Sakai inhabits the area around Unoshima. This lake was formed by lava flows from Mt. Fuji and related volcanoes, which dammed the streams coming down from the northern mountain ranges. The lake has no appreciable inflowing stream and lacks outflowing rivers. In its drainage basins, where porous volcanic deposits prevail, the runoff water mostly flows underground but rarely rises as surface stream. The eastern shore of the lake is partly surrounded by cultivated land. There are some towns and villages on the northeastern and southeastern shores. This lake is ice-covered from January to February and has a persistent thermocline in summer.

Many limnological studies have been carried out since the first intensive work by Miyadi (1932). Transparency averaged about $5 \mathrm{~m}$ in the late 1920's, when the hypolimnion was observed to be oxygen depletion in summer, suggesting that the lake had already reached a fairly advanced stage of eutrophication. In 193348 , the transparency showed summer increases, owing to the exhaustion of nutrients in the euphotic zone during the summer stratification. Since 1971, however, the extent of transparency has decreased to about $3.5 \mathrm{~m}$ due to the advance of eutrophication (Yamanashi Prefecture, 1993). Since the end of the 1950's, the cyanobacterium Microcystis aeruginosa Kutzing has bloomed annually in JulyAugust (Kadota, 1962). In 1986, a large region began to be serviced by a sewerage plant, which had been established by the local government. In the early summer of 1995, the dinoflagellate Peridinium spp. grew explosively, forming a freshwater red tide (Hirabayashi, unpublished data). Aizaki et al. (1981) ranked this lake as a

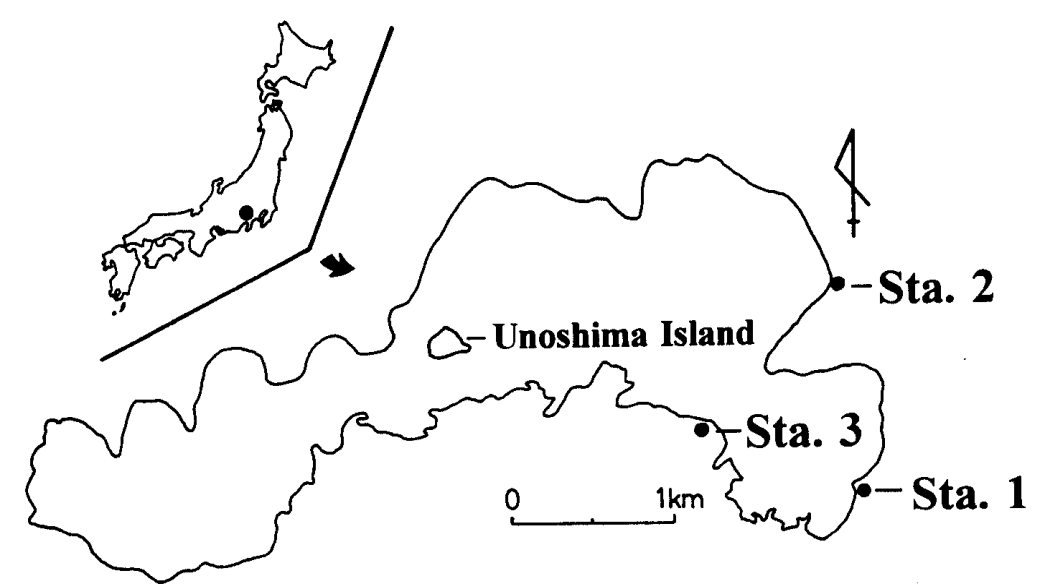

Fig. 1. A map showing the three sampling stations along the shoreline of Lake Kawaguchi. 
eutrophic-mesotrophic one, using the modified Carlson's trophic state index based on chlorophyll-a, total phosphorus, and transparency.

\section{Methods}

Chironomid midges were collected every day from March 18 to May 7 (51 days) in 1994, by the board trap (a plastic white board; $25 \times 9 \mathrm{~cm}$, sprayed with adhesive; polyolefin). The board trap was set on a pole about $1.5 \mathrm{~m}$ above ground level. We selected 3 sampling stations (Stas. 1-3) along the shoreline in the eastern part of the lake (Fig. 1). Table 1 shows the environmental condition of each station. Stas. 1 and 2 were on a man-made (artificial) shoreline. On the other hand, Sta. 3 was on a natural shoreline. In Stas. 2 and 3 , near the shoreline, the sediment was covered patchily with submerged plants, Elodea nuttallii (Planch) St. Joho. Moreover, around these stations, the surrounding vegetation (Miscanthus sp. and Salix sp.) was relatively richer than around Sta. 1. However, there were no submerged plants in Sta. 1. At night, the light source was uniform around the three stations during the investigation periods. Until now, most complaints concerned with massive flight of chironomid midges were reported from people living near Sta. 1.

A board trap was set up about half an hour before sunset $(16: 30-17: 30)$, and the next day (the same time) it was replaced with a new board trap. The adult chironomid midges trapped at each station were identified and counted in the laboratory.

During the investigation periods, chironomid adults were also caught qualitatively by sweeping with an insect net around Sta. 2 (10 March, 26 March, 14 April, 26 April, 9 May and 24 May). They were then mounted on slides in the laboratory and identified according to the keys of Pinder (1978) and Sasa and Kikuchi (1995). The weather data (daily mean air temperature and daily precipitation) of the Kawaguchiko Meteorological Observatory Station was used during the investigation periods.

\section{RESUlts}

The total number of adult midges caught by board traps at three stations are presented in Table 2 and the names of chironomid midges, including the sweeping net samples, are shown in Table 3 . A total of 38,498 adults were collected by board traps, $64.1 \%$ of which were trapped at Sta. 3 (24,705 individuals). On the other hand, the least number was trapped at Sta. 1 (1,493 individuals, $3.9 \%)$, which is approximately a ratio of $1: 17$ (Table 2 ). We identified a total of ten species belonging to two subfamilies, i.e., 7 species of Chironominae and 3 species of Orthocladiinae. Parachironomus arcuatus Goetghebuer, Polypedilum cultellatum Goetghebuer, $P$. nubeculosum Meigen, Psectrocladius yunoquartus Sasa, Cricotopus sylvestris Fabricius and Corynoneura fujiundecima Sasa only were collected by net sweeping (Table 3). The most abundant species was

Table 1. Environmental conditions of each sampling station along the shoreline of Lake Kawaguchi.

\begin{tabular}{cccccc}
\hline \hline $\begin{array}{c}\text { Station } \\
\text { No. }\end{array}$ & $\begin{array}{c}\text { Shoreline } \\
\text { of lake }\end{array}$ & $\begin{array}{c}\text { Distance from } \\
\text { shoreline }(\mathrm{m})\end{array}$ & $\begin{array}{c}\text { Height of above } \\
\text { water level }(\mathrm{m})\end{array}$ & $\begin{array}{l}\text { Conditions of } \\
\text { lake bottom }\end{array}$ & $\begin{array}{c}\text { Surrounding } \\
\text { vegetation }\end{array}$ \\
\hline 1 & artificial & 2 & 3 & $\begin{array}{l}\text { rock of lava } \\
(\phi 50-80 \mathrm{~cm})\end{array}$ & $\begin{array}{l}\text { poor } \\
\text { Miscanthus sp. } \\
\text { poor } \\
\text { sand } \\
\text { Elodea nuttallii } \\
\text { sand }\end{array}$ \\
3 & artificial & 10 & 5 & Elodea nuttallii & $\begin{array}{l}\text { Miscanthus sp. } \\
\text { Salix sp. }\end{array}$ \\
\hline
\end{tabular}


Table 2. Total numbers of adult midges caught by board traps at the three sampling stations from March 18 to May 7 in 1994.

\begin{tabular}{lrrrr}
\hline \multicolumn{1}{c}{ Station } & \multicolumn{1}{c}{ Sta. 1} & \multicolumn{1}{c}{ Sta. 2} & Sta. 3 & Total No. \\
\hline B. tsukubaensis & $1,217(3.2)$ & $12,142(32.0)$ & $24,552(64.8)$ & 37,881 \\
G. tokunagai & $246(56.9)$ & $109(25.3)$ & $77(17.8)$ & 432 \\
C. yoshimatsui & $9(9.7)$ & $39(41.9)$ & $45(48.4)$ & 93 \\
C. plumosus & $5(100)$ & $0(0)$ & $0(0)$ & 5 \\
Unidentified & $16(18.4)$ & $40(46.0)$ & $31(35.6)$ & 87 \\
\hline Total & $1,493(3.9)$ & $12,330(32.0)$ & $24,705(64.1)$ & 38,498 \\
\hline
\end{tabular}

Figures in parentheses show percentages.

Table 3. List of chironomid midges collected at Lake Kawaguchi from March to May in 1994.

\begin{tabular}{|c|c|c|c|}
\hline Species & Board trap & Sweeping net & Sasa $(1985)^{*}$ \\
\hline \multicolumn{4}{|l|}{ Subfamily CHIRONOMINAE } \\
\hline Biwatendipes tsukubaensis & $*$ & * & \\
\hline Chironomus yoshimatsui & $*$ & * & $*$ \\
\hline Glyptotendipes tokunagai & $*$ & * & $*$ \\
\hline Chironomus plumosus & $*$ & $*$ & \\
\hline Parachironomus arcuatus & & * & * \\
\hline Polypedilum cultellatum & & * & $*$ \\
\hline P. nubeculosum & & $*$ & * \\
\hline Glyptotendipes fujisecundus & & & * \\
\hline Chironomus fujitertius & & & $*$ \\
\hline Dicrotendipes pelochloris & & & * \\
\hline Pentapedilum sordens & & & * \\
\hline P. unifascium & & & $*$ \\
\hline Tanytarsus yunosecundus & & & $*$ \\
\hline T. oyamai & & & $*$ \\
\hline \multicolumn{4}{|l|}{ Subfamily ORTHOCLADIINAE } \\
\hline Psectrocladius yunoquartus & & * & $*$ \\
\hline Cricotopus sylvestris & & * & $*$ \\
\hline Corynoneura fujiundecima & & $*$ & \\
\hline Limnophyes fujinonus & & & $*$ \\
\hline L. fujidecimus & & & * \\
\hline
\end{tabular}

* Sasa (1985), in which midges were collected on 9 and 10 July, 1981, and 13 and 14, May, 1983.

Biwatendipes tsukubaensis Sasa et Ueno (37,881 individuals; 98.4\%), which was collected at all stations, especially, at Sta. 3 (24,552 individuals; $64.8 \%)$. Glyptotendipes tokunagai Sasa (432 individuals; $1.1 \%$ ) and Chironomus yoshimatsui Martin et Sublette (93 individuals; $0.2 \%$ ) were also collected at all stations, although the overall number was very low. Most of the former were trapped at Sta. 1, whereas the latter were trapped more at Stas. 2 and 3.

Figure 2 shows the total number of the three main chironomid species, $B$. tsukubaensis, G. tokunagai and C. yoshimatsui, trapped at all stations. Daily mean air temperature and precipitation are also shown. Daily mean air temperature changed between $-0.3^{\circ} \mathrm{C}$ (March 20)$16.4^{\circ} \mathrm{C}$ (April 24) and varied periodically. There were a few days which were below $2{ }^{\circ} \mathrm{C}$, but the temperature tended to increase during the investigation periods. The precipitation was recorded on 13 days from March 18 to May 7. Precipitation in excess of $10 \mathrm{~mm}$ was recorded only on 3 days. The maximum precipitation was $26.5 \mathrm{~mm}$ on May 2, followed by $19 \mathrm{~mm}$ on March 28.

B. tsukubaensis was trapped from midMarch to early May, with two peaks oc- 


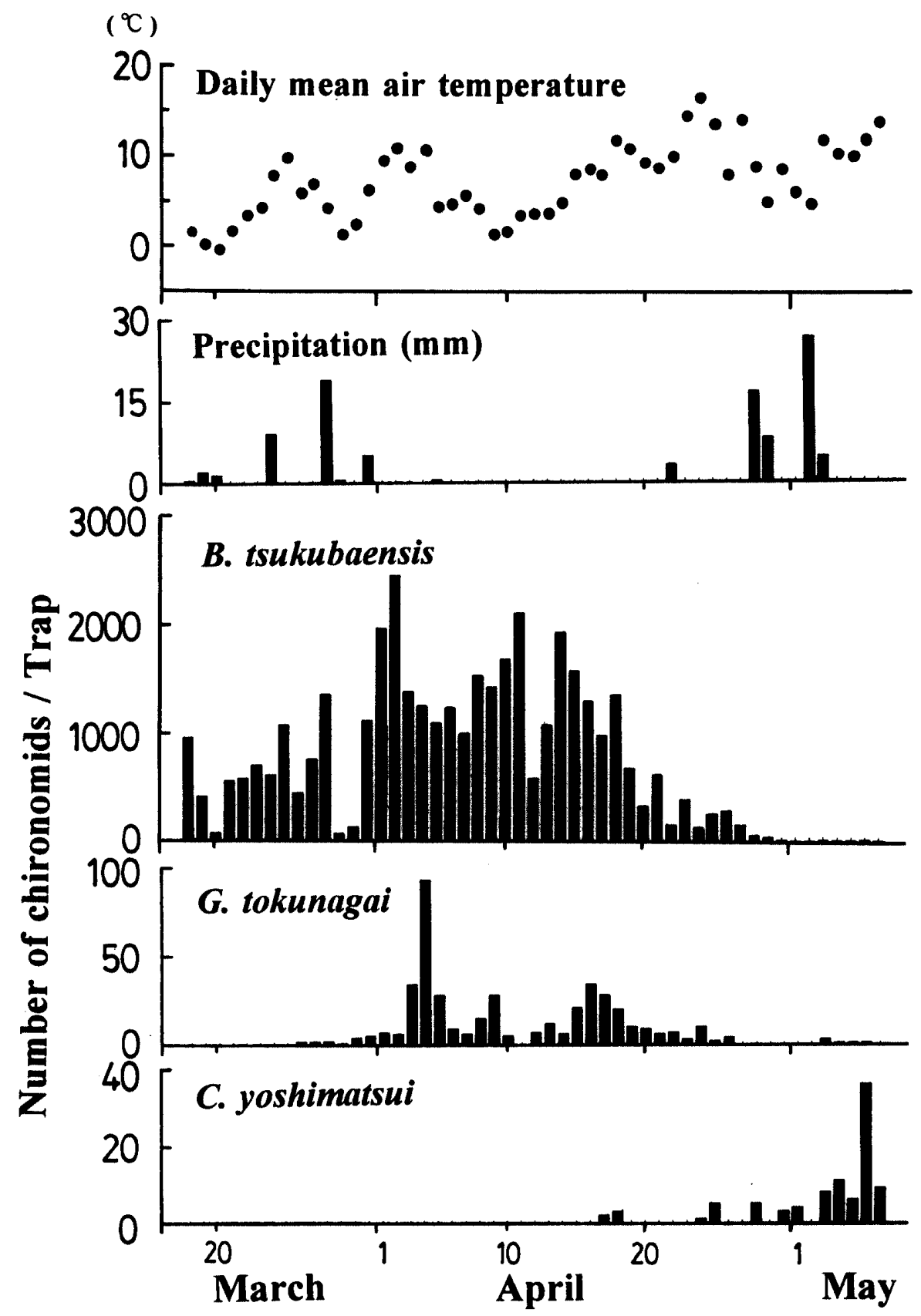

Fig. 2. Fluctuations in the total numbers of three main chironomid adults (B. tsukubaensis, $G$. tokunagai and $C$. yoshimatsui) trapped by board traps at three stations, the daily mean air temperature and daily precipitation in the spring season.

curring in early April and mid-April. In the case of $G$. tokunagai, which was trapped from late March to early May, two peaks also occurred in early April and mid-April. C. yoshimatsui began to be trapped from mid-April. C. plumosus was collected only at Sta. 1 from early May to the end of this investigation, though the number was very low.

The number of adult midges collected seems to be influenced by weather conditions. On the days of low mean air temperature and/or much precipitation few adult midges were trapped, i.e., on March 20, 2930, and April 12.

Figure 3 shows the number of male and female $B$. tsukubaensis trapped at three stations. The ratio of male to female was $10: 1$, and most of the midges collected were males. Fluctuations in the numbers 


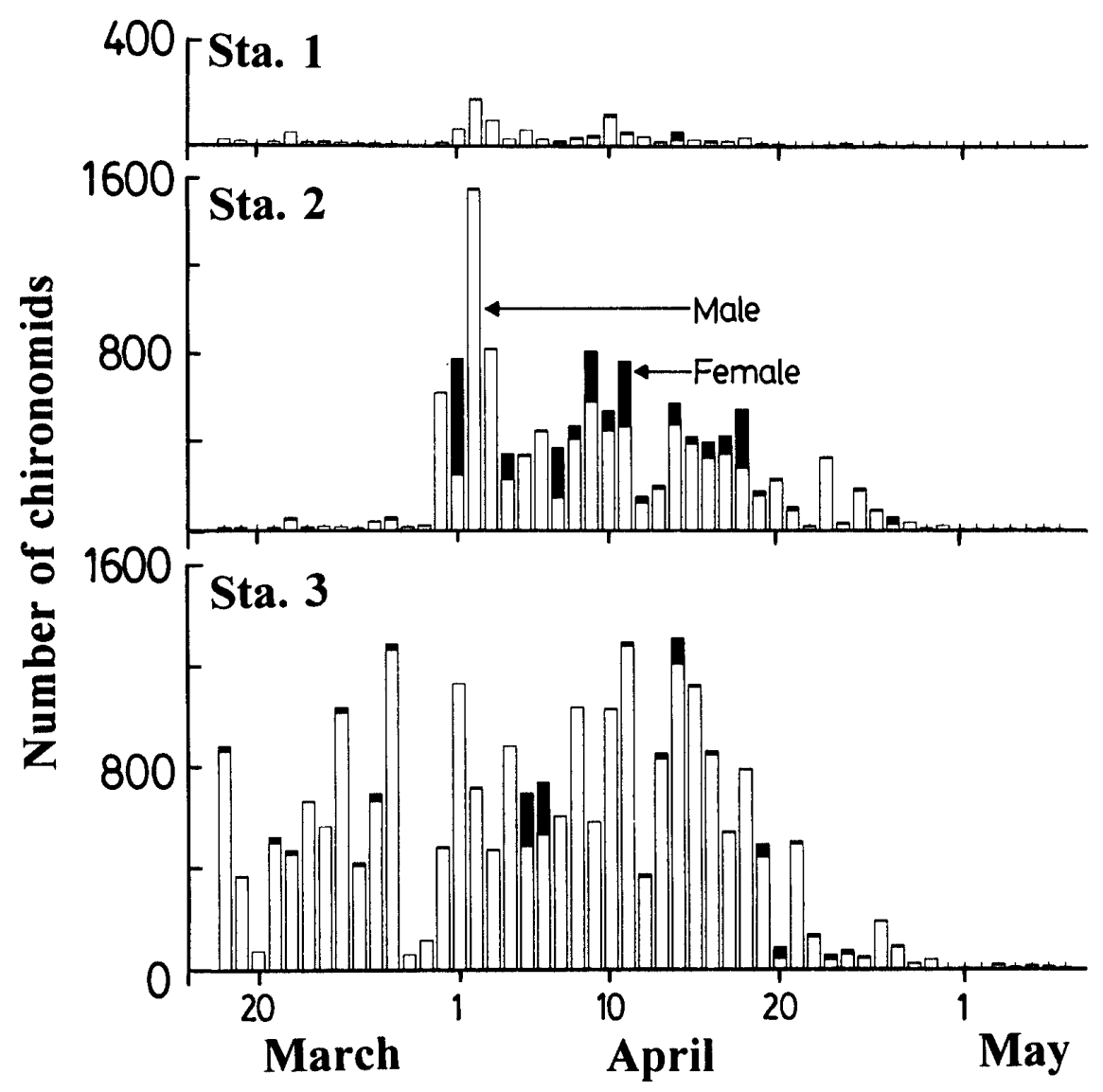

Fig. 3. Fluctuations in the number of adult midges, $B$. tsukubaensis, caught in board traps at three stations in the spring season.

of midges at Stas. 1 and 2 were similar, i.e., very few midges were trapped during March. At Sta. 3 more than 500 individuals per trap were collected continually from mid-March to mid-April, and two peaks were found, in late March and midApril.

\section{Discussion}

Several researchers have reported on the benthic macroinvertebrate including chironomid larvae, in the profundal region of Lake Kawaguchi (Miyadi, 1932; Kitagawa, 1973; Yasuno et al., 1983), and recently, Hirabayashi et al. (1995) reported the horizontal distribution of benthic macroinvertebrate in the profundal and sublittoral regions. They indicated the average density of the benthic community for the entire lake was 6,745 ind. $\cdot \mathrm{m}^{-2}$ and was comprised mainly of oligochaetes
(81.4\%) and chironomids (19.6\%). Moreover, they reported heavy density of populations in $C$. plumosus and $T$. akamusi larvae in the profundal region of this lake, and T. akamusi and C. plumosus larvae in chironomid communities were 50.5\% (634 \pm 280 ind. $\left.\cdot \mathrm{m}^{-2}\right)$ and $27.1 \% \quad(341 \pm 182$ ind. $\cdot \mathrm{m}^{-2}$ ), respectively. So far, the massive emergence of these chironomid species has seemed to create a serious nuisance as well as economic problems for people living near the lake even in the spring season. However, the results of our investigation showed that $B$. tsukubaensis inhabited along the shoreline and created a serious nuisance.

The chironomid fauna in the littoral and hydrophyte zone is little known in Lake Kawaguchi. Sasa (1985) reported 16 species collected around the lake on 9-10 July 1981 and on 13-14 May 1983, but B. tsukubaensis is not found in his report (Table 
$3)$.

In Lake Kawaguchi, C. plumosus and T. akamusi were known to be dominant in the profundal region, but $B$. tsukubaensis seems to be dominant in the littoral region.

A higher diversity in chironomid fauna was observed in the hydrophyte region than in the profundal region (Kondo and Hamashima, 1985; Ueno et al., 1993). The present study showed that $B$. tsukubaensis predominated at all sampling stations, and most adult midges trapped at Sta. 3 were this species. This station was on a natural shoreline and covered with submerged plants, with rich surrounding vegetation. It seemed that heavy density of populations in chironomid larvae in the hydrophyte region created massive emergence of adult midges there. However, most complaints concerned with massive flight of chironomid adults were reported every spring from people living near Sta. 1. This station was on a man-made shoreline and not covered by submerged plants, and the surrounding vegetation was poor. We considered that most adult midges were trapped by the surrounding vegetation (some plants, trees and grasses), after they emerged from the hydrophyte region at Sta. 3. The surrounding vegetation plays an important role in keeping midges from human living areas. Hirabayashi (1991a, b, c) also pointed out the same facts regarding $T$. akamusi adult midges around the Lake Suwa area. As one of the useful countermeasures, we propose increasing the vegetation area (including parks, etc.) along the shoreline.

\section{ACKNOWLEDGEMENTS}

We are grateful to Dr. M. Yamamoto of the Kankyo-Kagaku Co., Ltd. and Mr. M. Tutumi, Dr. S. Tobita, Mr. K. Yoshizawa and Mr. M. Horiuchi of the Environmental Studies Division, Yamanashi Institute for Public Health, for their helpful suggestions and observations. We also wish to express our thanks to the members of the Shizenkagaku-doukoukai Kawaguchiko High School (Messrs. T. Aizawa, Y.
Kagami, M. Watanabe, M. Katumata and K. Takahashi) for their assistance during the course of this survey. This research was supported by a grant from Nissan Science Foundation.

\section{REFERENCES}

Ali, A. (1980) Nuisance chironomids and their control: A review. Esa Bull., 26: 3-16.

Ali, A. (1991) Perspectives on management of pestiferous Chironomidae (Diptera), an emerging global problem. J. Am. Mosq. Cont. Assoc., 7: 260-281.

Aizaki, M., A. Otsuki, T. Fukushima, T. Kawai, M. Hosomi and K. Muraoka (1981) Application of modified Carlson's trophic state index to Japanese lake and its relationships to other parameters related to trophic state. Res. Rep. Natl. Inst. Environ. Stud., 23: 13-31. (in Japanese with English summary).

Hirabayashi, K. (1991a) Studies on the massive flights of chironomid midges (Diptera: Chironomidae) as nuisance insects and plants for their control in the Lake Suwa Area, Japan. 1. Occurrence of massive flights of Tokunagayusurika akamusi. Jpn. J. Hyg., 46: 652-661 (in Japanese with English summary).

Hirabayashi, K. (1991b) Studies on the massive flights of chironomid midges (Diptera: Chironomidae) as nuisance insects and plants for their control in the Lake Suwa Area, Japan. 2. Quantitative evaluations of the nuisance of chironomid midges. Jpn. J. Hyg., 46: 662-675 (in Japanese with English summary).

Hirabayashi, K. (1991c) Studies on the massive flights of chironomid midges (Diptera: Chironomidae) as nuisance insects and plants for their control in the Lake Suwa Area, Japan. 3. Some experimental trials for control of nuisance midges and proposed counterplans. Jpn. J. Hyg., 46: 676-687 (in Japanese with English summary).

Hirabayasi, K., K. Yoshizawa and M. Horiuchi (1995) Horizontal distribution of benthic macroinvertebrates in Lake Kawaguchi, Japan. Res. Suwa Hydrobiol., 9: 121-129.

Igarashi, T., G. Murakami, Y. Adachi, M. Matsuno, Y. Saeki, T. Okada, K. Kawai, A. Kumagai and M. Sasa (1987) Common occurrence in Toyama of bronchial asthma induced by chironomid midges. Jpn. J. Exp. Med., 57: 1-9.

Ishii, A., T. Miyamoto, T. Shibuya and T. Igarashi (1988) Chironomid midges in the recent environment: A possible role as a causative agent allergic 
disease. Res. Rep. Nissan Sci. Foun., 11: 79-88 (in Japanese with English summary).

Kadota, S. (1962) On the plankton of the Lake Kawaguchi in summer, 1958. Bull. Coll. Agr. \& Vet. Med., Nihon Univ., 15: 54-61 (in Japanese).

Kay, A. B., M. O. Gad El Rab, J. Stewart and H. H. Erwa (1978) Widespread IgE-mediated hypersensitivity in Northern Sudan to the chironomid Cladotanytarsus lewisi ('green nimitti'). Clin. Exp. Immunol., 34: 106-110.

Kitagawa, N. (1973) Studies on the bottom fauna of Lakes Fujigo-ko and Ashino-ko. Rikusui fueiyouka no kisotekikenkyu, 2: 32-37 (in Japanese).

Kondo, S. and S. Hamashima (1985) Chironomid midges emerged from aquatic macrophytes in reservoirs. Jpn. J. Limnol., 46: 50-55.

Miyadi, D. (1932) Studies on the bottom fauna of Japanese lakes. 2. Mountain lakes of the tributaries of the River Tone, with special reference to azoic. Jpn. J. Zool., 3: 259-297.

Murakami, G., T. Igarashi, Y. Saeki, Y. Adachi, M. Matsumoto, T. Okada, K. Kawai, A. Kumagai and M. Sasa (1986) Clinical studies of bronchial asthma induced by chironomid midges. Jpn. J. Allergol., 35: 393-401 (in Japanese with English summary).

Pinder, L. C. V. (1978) A key to the adult males of the British Chironomidae (Diptera). Freshwater Biol. Assoc. Publ., 37: 1-169.

Sasa, M. (1985) Studies on the chironomids collected from Lakes in the Mount Fuji Area (Diptera, Chironomidae). Res. Rep. Natl. Inst. Environ. Stud., 83: 101-160.

Sasa, M. and M. Kikuchi (1995) Introduction. In: Chironomidae (Diptera) of Japan (ed., Sasa, M. and M. Kikuchi), pp. 3-15, University of Tokyo Press, Tokyo.

Tabaru, Y., K. Moriya and A. Ali (1987) Nuisance midges (Diptera: Chironomidae) and their control in Japan. J. Am. Mosq. Cont. Assoc., 3: 45-48.
Ueno, R., T. Iwakuma and S. Nohara (1993) Chironomid fauna in the emergent plant zone of Lake Kasumigaura, Japan. Jpn. J. Limnol., 54: 293-303.

Yamanashi Prefecture (1993) The Water Quality of Fuji Five Lakes During 21 Years, 138 pp., Kofu.

Yasuno, M., T. Iwakuma, Y. Sugaya and M. Sasa (1983) Zoobenthos of Japanese lakes of different trophic status, with special reference to Chironomidae. Res. Rep. Spec. Res. Proj. Natl. Inst. Environ. Stud., 182-R12-17: 21-48. (in Japanese).

\section{摘要}

春期, 河口湖周辺域に大量飛来する “不快昆虫” としてのユスリカ成虫に関する研究 平林公男" 渡边信介 ${ }^{21}$

") 山梨県立女子短期大学・一般教育科・生物 （广400 甲你市飯田 5-11-1） ${ }^{2)}$ 山梨県立富士河口湖高校・生物

（干401-03 南都留郡河口湖町船津 6663-1）

毎年, 春期に河口湖湖岸のホテルや民家に大量飛来す るユスリカ類の種類と発生量，発生消長を明らかにする ために, 1994 年 3 月から 5 月にかけて, 湖東部の湖岸 3 地点にボードトラップを設置し調查を行った。 調查期 間中, 3 地点で合計 38,498 匹の成虫が捕萑され，その内 の 98.4\% が Biwatendipes tsukubaensis Sasa et Ueno であった．次いで多く捕萑されたのは Glyptotendipes tokunagai Sasa で全体の 1.1\% であった. Chironomus yoshimatsui Martin et Sublette टC. plumosus Linnaeus も捕萑できたが, 個体数は少なかった.

湖から発生するユスリカ類は時間の経過とともに優占 種が交代した．すなわち，3 月中旬からB. tsukubaensis が捕萑され始め，時期をずらして G. tokunagai が 3 月 下旬から捕獲された. 次いで C. yoshimatsui が 4 月中旬 に，5月初旬になるとC. plumosus が捕獲され始めた. このように数種類のユスリカ類の羽化期が春期に重なる ことが, 湖周辺域に住む住民にとって，春期に多くのユ スリカ成虫が湖岸域に飛来するといった印象を持たせる と思われた。 